\title{
Ultrasound Imaging of the Fetal Palate
}

\author{
Hong Soo Wong ${ }^{1,2}$ and Kevin Craig Pringle 2 \\ ${ }^{1}$ Australian Women's Ultrasound Centre, Brisbane, Queensland \\ ${ }^{2}$ Department of Obstetrics and Gynaecology \\ School of Medicine and Health Sciences, University of Otago, Wellington \\ ${ }^{1}$ Australia \\ ${ }^{2}$ New Zealand
}

\section{Introduction}

Ultrasound examination of the fetal palate is known to be problematic. The difficulties identified include shadowing by facial bones, its curved anatomy, and its location deep inside the fetal head especially for the posterior part of palate. The soft tissues in the area, e.g. the fetal tongue, also make it more difficult to delineate the palate. Antenatal detection rate of fetal cleft palate has remained low especially when it is an isolated defect without concomitant cleft lip. The reported detection rate is virtually $0 \%$ in these cases (Grandjean et al., 1999; Clementi et.al.. 2000; Shaikh et.al., 2001; Wayne et al., 2002; Hanikeri et al., 2006; Offerdal et al., 2008; Demircioglu et al., 2008). Various methods for examination of the fetal palate have been proposed, including the use of 2-dimensional (2D) and 3-dimensional (3D) ultrasound technology. In this chapter, ultrasound imaging of the fetal palate will be revisited. How these problems may be resolved with ultrasound technology will be discussed.

\section{The development of the fetal palate}

The fetal palate forms between week 5 to 12 (Moore \& Persaud, 2003).

Early in the $6^{\text {th }}$ week, the medial nasal prominences merge to form the median palatine process, or the primary palate, the premaxillary part of the maxilla.

The secondary palate develops early in the $6^{\text {th }}$ week from the lateral palatine processes or the palatal shelves. They are 2 mesenchymal projections that extend from the internal aspects of the maxillary prominences. They elongate and ascent to a horizonatal position superior to the tongue at the $7^{\text {th }}$ to $8^{\text {th }}$ week, fuse with the nasal septum and the posterior part of the primary palate. The primary and secondary palates become ossified. The posterior part of the lateral palatal processes extends beyond the nasal septum forming the soft palate and uvula, and does not become ossified. (Fig. 1)

The fetal palate curves from the premaxilla to the tip of the uvula making almost a 90 degrees turn (Fig. 2). It is like a part of a sphere, with every point on it making a different tangent to any reference plane one may set on this sphere.

Facial clefts could be unilateral, bilateral or midline; anterior, involving the lip with or without the primary palate, or posterior, involving the secondary palate, with or without 
involvement of the lip and primary palate, or sometimes involving the uvula only. Overall about a quarter of the facial clefts involve the lip, one half both the lip and palate, and a

(a)
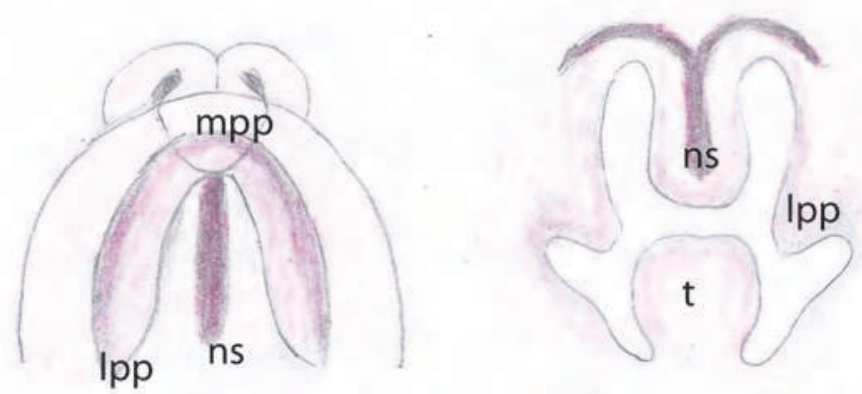

(b)
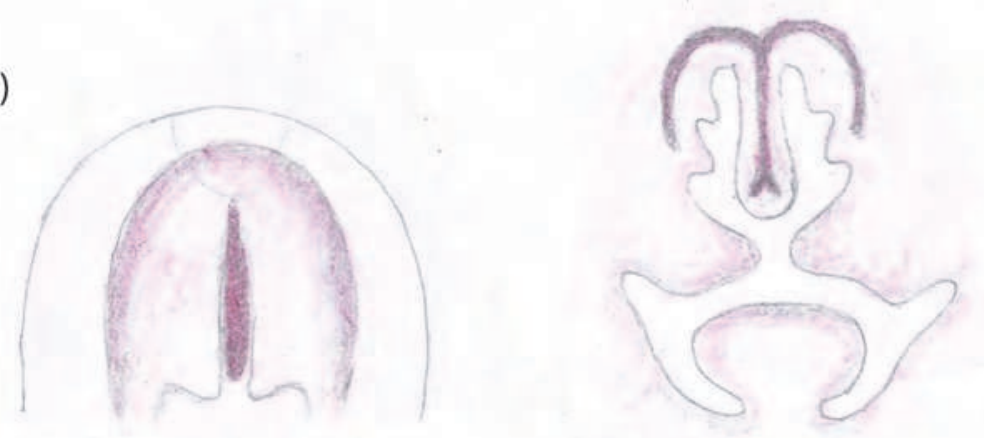

(c)
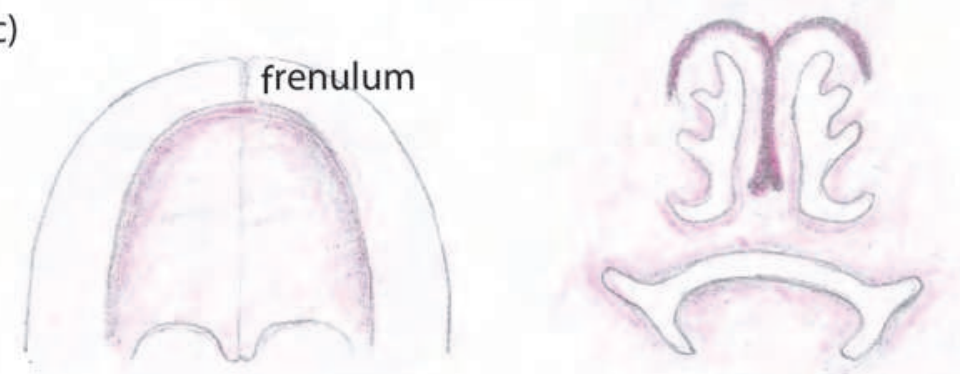

Fig. 1. Development of the fetal palate from the seventh (a), eighth (b) to the tenth (c) week. The images on the left: the palate as seen from below; on the right, coronal plane through the nasal septum and the developing palate; mpp, median palatine process; lpp, lateral palatine process; $\mathrm{ns}$, nasal septum; $\mathrm{t}$, tongue. 


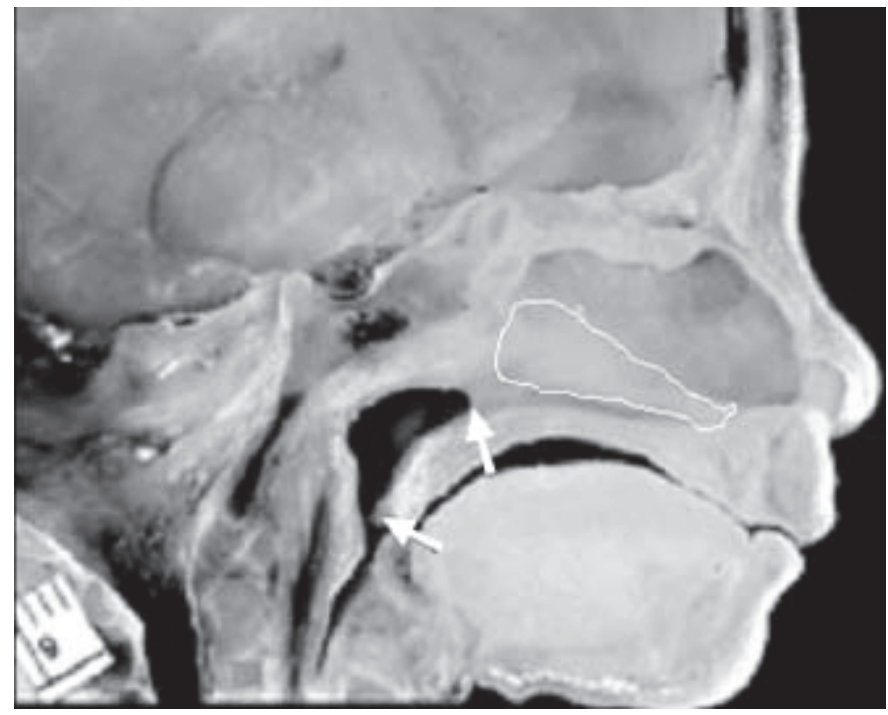

Fig. 2. Sagittal section of a 24 weeks fetus. The soft palate is between the arrows. The vomer bone is outlined. From "Prenatal ultrasound examination of the secondary palate" by Prof. Stuart Campbell, picture courtesy of Dr. Gonzalo Moscoso with thanks, in Ultrasound Obstet Gynecol 2007; 29(2): 124-127. Copyright International Society of Ultrasound in Obstetrics and Gynecology, 2007. Reproduced with permission. Permission is granted by John Wiley \& Son Ltd. on behalf of the ISUOG.

quarter the palate only (Offerdal 2008). Therefore assessment of the fetal lip or palate is not complete without the examination of both and the examination of the palate extends from the premaxilla to the tip of the uvula.

\section{The use of ultrasound in imaging the fetal palate}

\subsection{Two-dimensional ultrasound}

Before the advent of 3D ultrasound, facial clefts were diagnosed by the $2 \mathrm{D}$ oblique face view (Pilu et al., 1986)(Fig. 3). The presence of cleft lip detected in this view leads to further assessment of the fetal palate.

The conventional assessment of the fetal face and anterior part of the palate involves the evaluation of these structures in the axial and coronal planes, which could be obtained in 6895\% of fetuses in the mid-trimester (Pretorius 1995, Babcook 1996). The structures to be assessed in the orthogonal planes are as follows:

\begin{tabular}{|l|l|l|}
\hline Coronal plane & Axial plane & Sagittal view \\
\hline Soft tissue in the upper lip & Soft tissue of upper lip & Soft tissue of upper lip \\
\hline - & $\begin{array}{l}\text { Alveolar ridge of the } \\
\text { maxilla }\end{array}$ & $\begin{array}{l}\text { Any presence of pre- } \\
\text { maxillary protrusion }\end{array}$ \\
\hline
\end{tabular}

Table 1. The structures to be evaluated on the conventional 2D planes in assessment of fetal lip and palate 


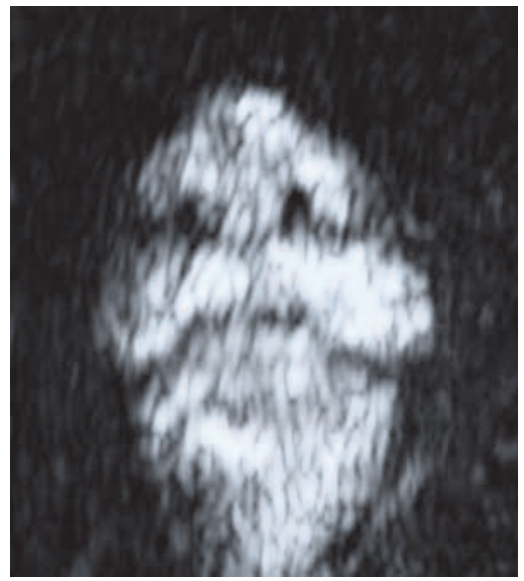

Fig. 3. The $2 \mathrm{D}$ view through the lower part of the fetal face showing the nose and the lips.

The sagittal view (or the facial profile) is not always helpful especially in the case of unilateral facial cleft because the view could be very much near normal.

The primary palate and part of the secondary palate are bony. The soft palate including the uvula, is made up of soft tissue. The primary palate is superficial, lying just behind the fetal lip. In contrast, the secondary palate has a dome further inside the head, enclosed by the facial bones (Fig. 2). There are soft tissues present close to the secondary palate in the area e.g. the fetal tongue and the pharynx. The presence of fluid in the oral and pharyngeal cavity and the movement of the tongue may help to define the palate. However, it is known that the hard palate is more difficult to define consistently and the soft palate could not be recognised discretely on 2D ultrasound (Filly \& Feldstein, 2000).

\subsection{Three-dimensional ultrasound}

Ulm et al (1998) used 3D ultrasound to evaluate fetal tooth germs and found it superior to 2D ultrasound with a detection rate of $88-94 \%$ versus $56-62 \%$, and noted its usefulness for characterization of facial clefts (Uml et al., 1999).

Fig. 4 and Fig. 5 show the axial plane of the palate in same fetus in 2D and 3D respectively. The application of 3D ultrasound allows the clear visualization of the alveolar ridge in details. The application of 3D ultrasound allows the clear visualization of the alveolar ridge. Johnson et al. (2000) pointed out the advantages of 3D ultrasound:

a. The fetal face may be viewed in a standard orientation.

b. Interactive display allows the manipulation and scrutinization without the concern for fetal movement

c. Allow artefacts to be detected

d. Allow serial views

e. Allow exact location of the planar images be identified in relation to the rendered image

f. The rendered image allows the family to see the fetal abnormality and the associated abnormality.

Up to this time, shadowing by the alveolar ridge and the facial bones is still an issue for viewing the secondary palate even on 3D ultrasound. Campbell \& Lees (2003) introduced the use of three-dimensional reverse face (3D RF) view for the diagnosis of cleft palate (Fig. 6). The usefulness of this technique in the antenatal diagnosis of cleft palate was confirmed 


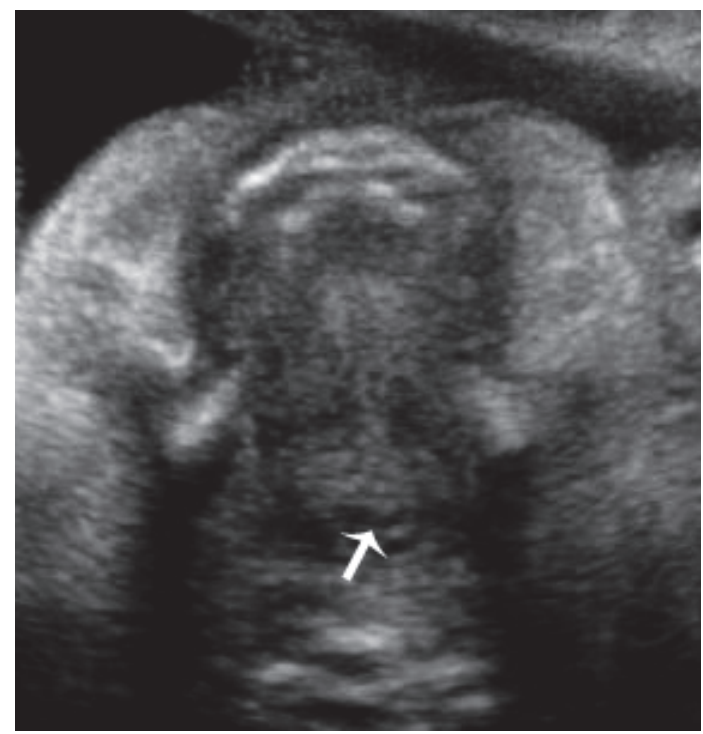

Fig. 4. 2D ultrasound image of the plate. The primary and secondary palate can be seen in this axial plane. The posterior nasal spine is indicated by the arrow. However, due to the anatomy of the palate, the under-surface of the soft palate cannot be seen because it is almost vertical to the insonation beam (Please refer to Fig. 2).

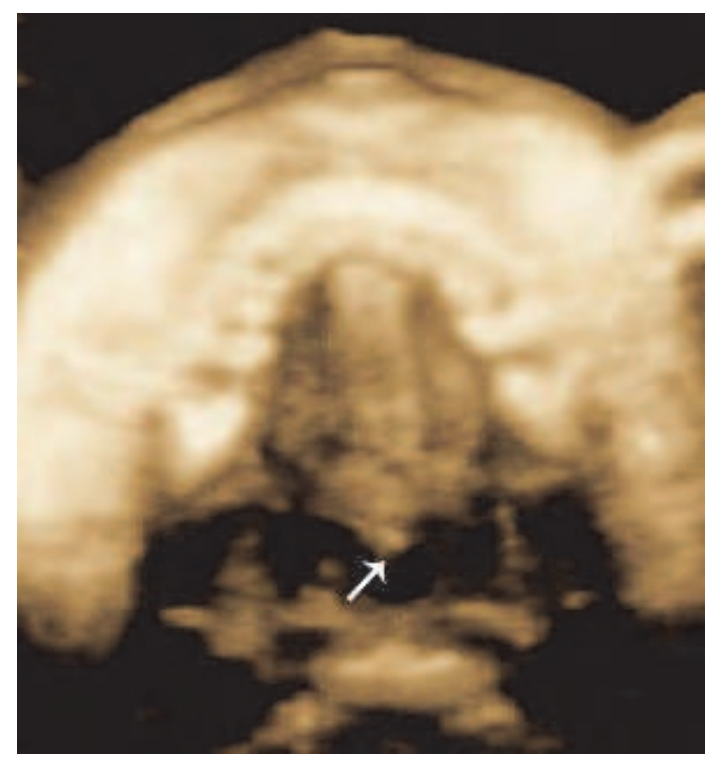

Fig. 5. Axial view on 3D ultrasound. The alveolar ridge is clearly shown in 3D compared with the 2D image in the same fetus in Fig. 4. The arrow points to the tip of the uvula, with the posterior nasal spine in the background. 
in 8 cases of suspected craniofacial clefts except in a case of a cleft in the soft palate (Campbell et al., 2005). The face is turned through 180 degrees to be viewed in the reverse direction after a $3 \mathrm{D}$ volume is obtained on the fetal face. The shadowing by the alveolar ridge could be largely avoided with clearer demarcation of the edge of the facial cleft with this method.

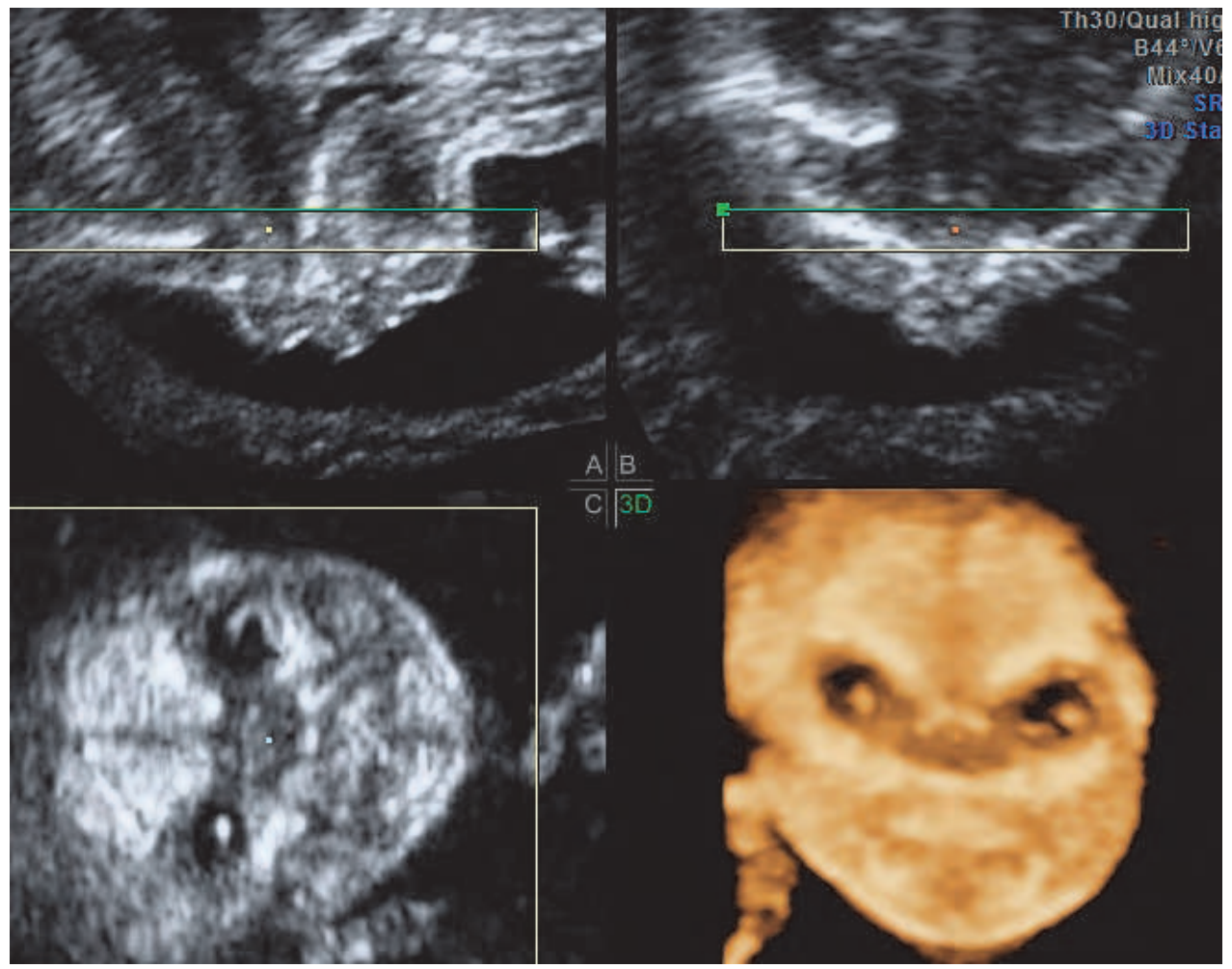

Fig. 6. The reverse face view. The intact palate can be seen as a distinct horizontal line separating the nasal and the oral cavities.

To avoid acoustic shadowing from the alveolar ridge, Pilu \& Segata (2006) suggested that the secondary palate to be insonated at a 45 degrees angle in the sagittal plane and 3D ultrasound to be used to construct axial and coronal planes (Fig. 7).

With this method, they were able to obtain satisfactory views of the secondary palate in 10 of 15 cases between 19-28 weeks. They examined the tomographic ultrasound images (TUI) in the orthogonal planes. They confirmed that the axial plane (Fig. 8) allowed the assessment of alveolar ridge defect in cleft lip and palate. However, the tongue might still obscure the edges of the defect in facial cleft. Tomographic ultrasound images of the secondary palate in the coronal plane (Fig. 9) allowed the examination of the secondary palate in serial sections along its length and the edges of the defect appeared to be demarcated. This echoes the finding of Campbell et al. (2003). Although part of the soft palate could be visualized in the sagittal plane, it was not demonstrated in the axial and coronal planes. The limitation with this technique is unfavourable fetal position. (Pilu \& Segata 2006) 


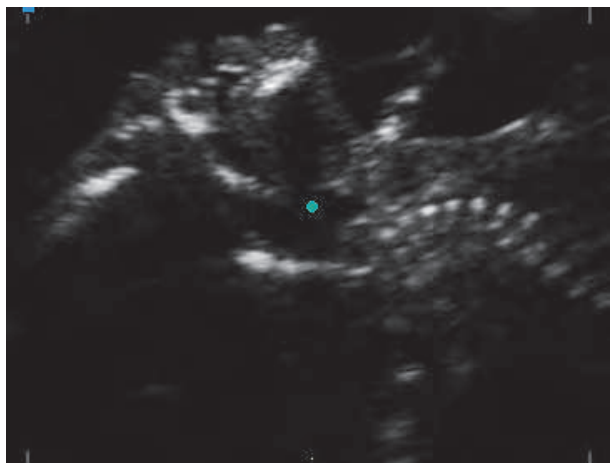

Fig. 7. Insonation of the fetal palate at an angle to avoid acoustic shadowing by the alveolar ridge.

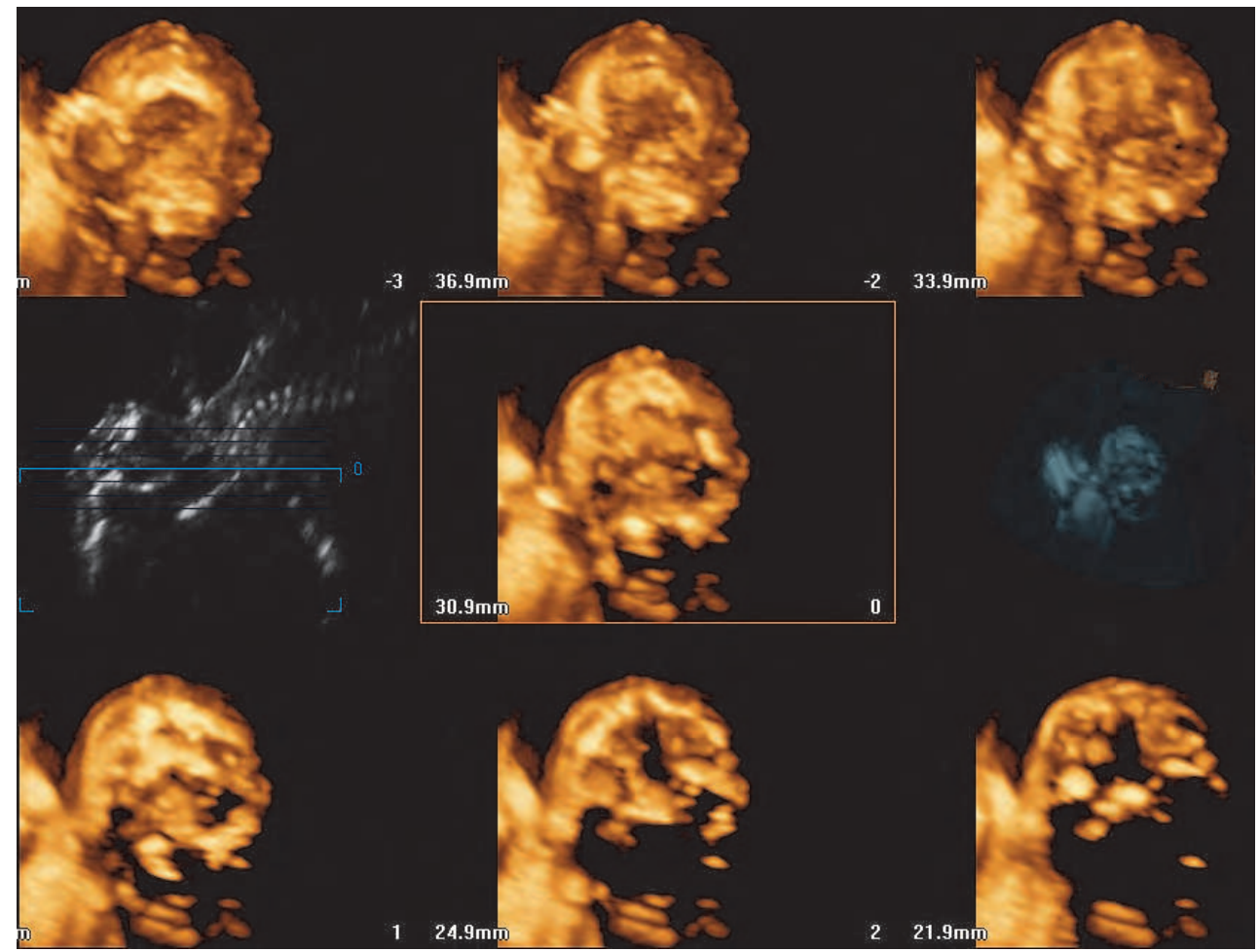

Fig. 8. TUI of the axial view 


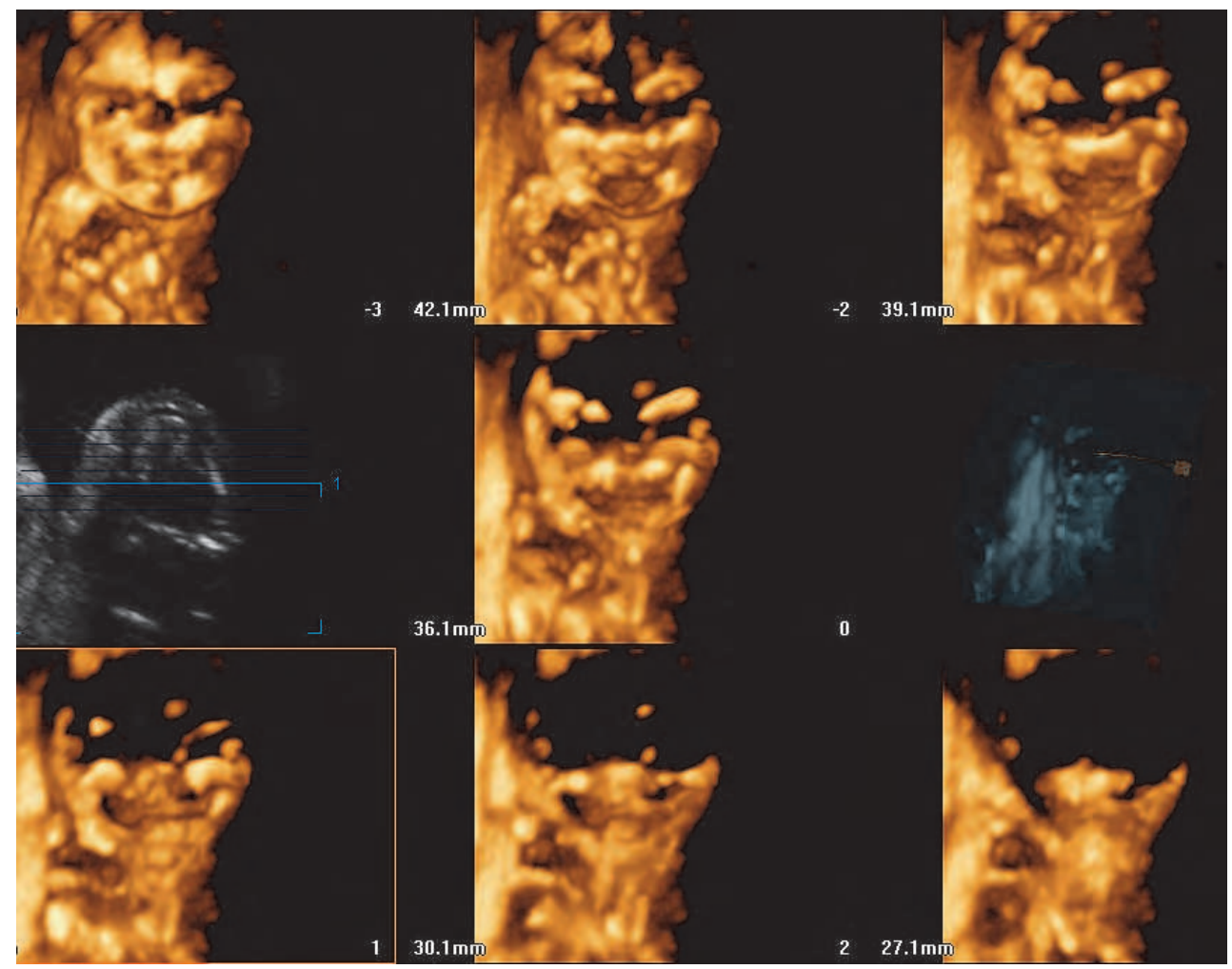

Fig. 9. TUI of the coronal view. The coronal views of the secondary palate could be assessed along the length of the palate in a serial fashion. 
Platt et al. (2006) demonstrated the use of the "flipped face" view in antenatal diagnosis of facial clefts. Following acquisition of the $3 \mathrm{D}$ volume of the fetal face, the volume is rotated to view the palate from below in a thick slice (Fig. 10). They commented that with this method, the full length and width of the mouth and palate in the axial plane could be examined in 2 minutes.

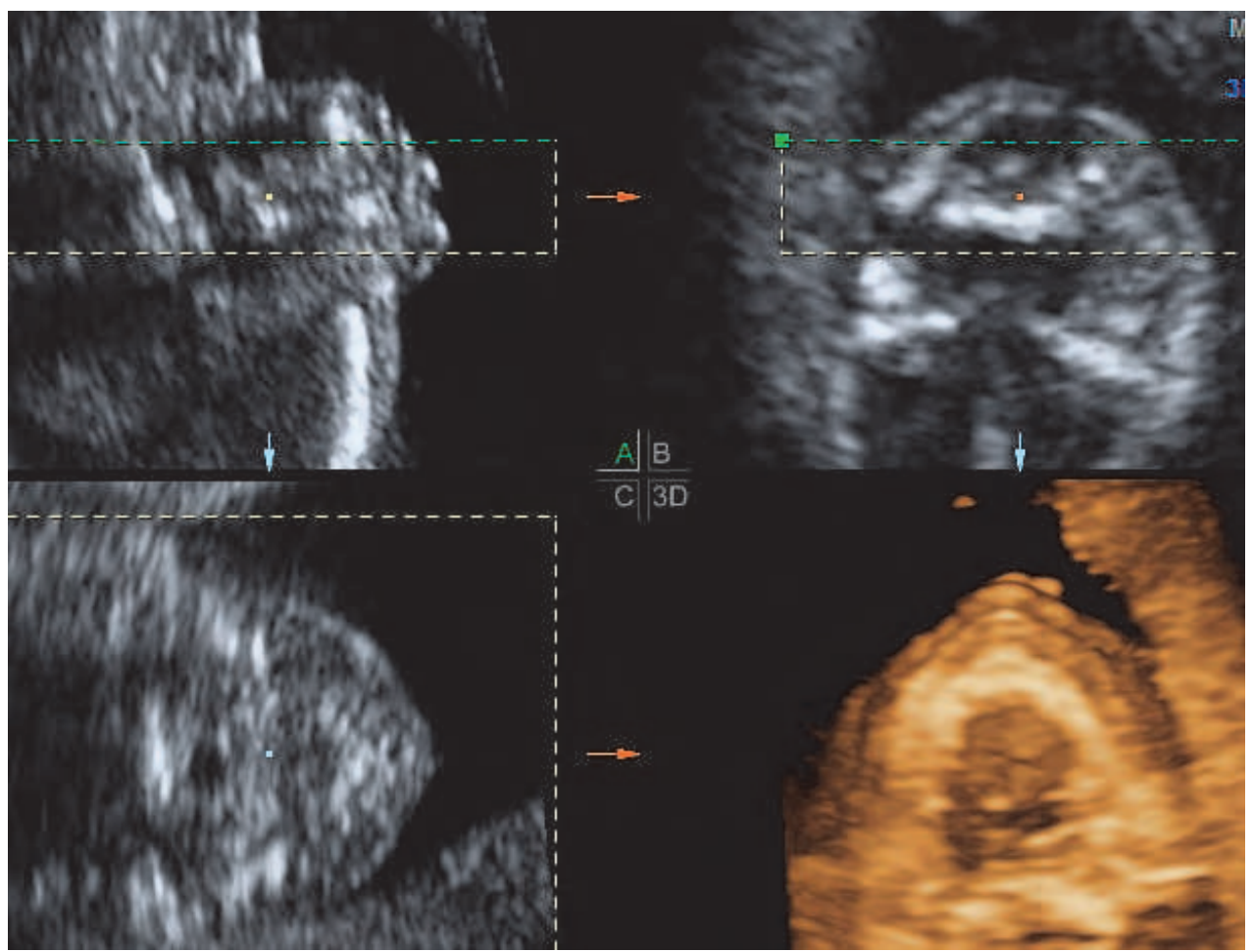

Fig. 10. The "flipped face" view. The alveolar ridge is well seen in this fetus at 18 weeks. The tip of the uvula is visible.

Wong et al $(2007,2008,2009$, and 2010) proposed a rotational method to view the secondary palate especially the soft palate, by rotating the orthogonal planes including the "flipped face" view and the reverse face view to the oblique planes (Fig. 11). With this method, one could view the surfaces of the soft palate at different angles from above or below or from the side with a stored 3D volume of the face. The uvula allows the soft palate to be identified (Fig. 5). The soft tissue around the palate does not appear to affect the view. Similar to the reverse face view, the shadowing by the facial bones and alveolar ridge could largely be avoided because the insonation plane is different from the examination plane.The authors reported the usefulness of this technique in assessing the extent of fetal cleft palate (Wong et al., 2010). However, the application of this method in assessing isolated clefts in the soft palate remains to be tested as this is a less common entity. 


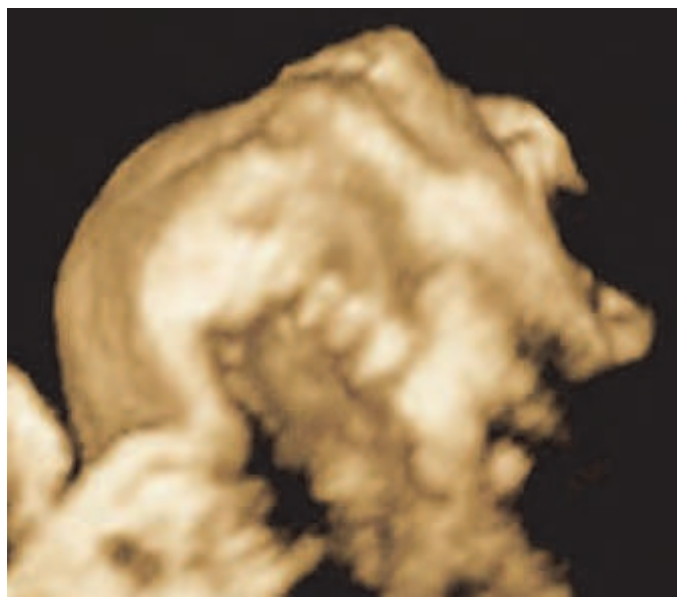

Fig. 11. The oblique axial plane. This is obtained by rotating the axial plane to an oblique plane. The under-surface of the soft palate including the uvula could be seen.

\section{Conclusion}

We have witnessed the advancement of ultrasound technology in the last few decades, and the increase use of 3D ultrasound in the examination of the fetus in the past 20 years. All the precious experience by previous researchers has contributed to our understand of the issues in the application of ultrasound on examination of the fetal palate and the ways to overcome them. We look forward to see what appears to be a difficult task in the past may possibly be incorporated into routine ultrasound examination of the fetus.

\section{References}

Grandjean H, Larroque D \& Levi S. The performance of routine ultrasonographic screening of pregnancies in the Eurofetus Study. American Journal of Obstetrics and Gynecology, Vol 81, No. 2 (August 1999), pp. 446-454., ISSN 0002-9378

Clementi M, Tenconi R, Bianchi F \& Stoll C. Evaluation of prenatal diagnosis of cleft lip with or without cleft palate and cleft palate by ultrasound: experience from 20 European registries. EUROSCAN study group. Prenatal Diagnosis, Vol. 20, No. 11 (November 2000), pp. 870-875, ISSN 1097-0223

Shaikh D, Mercer NS, Sohan K, Kyle P \& Soothill P. Prenatal diagnosis of cleft lip and palate. British Journal of Plastic Surgery, Vol. 54, No. 4 (June 2001), pp. 288-289, ISSN 00071226

Wayne C, Cook K, Sairam S, Hollis B \& Thilaganathan B. Sensitivity and accuracy of routine antenatal ultrasound screening for isolated facial clefts. British Journal of Radiology, Vol. 75, No. 895, (July 2002), pp. 584-589, ISSN 1748-880X

Hanikeri M, Savundra J, Gillett D, Walters M \& McBain W. Antenatal transabdominal ultrasound detection of cleft lip and palate in Western Australia from 1996 to 2003. Cleft Palate Craniofacial Journal, Vol. 43, No. 1, (January 2006), pp. 61-66, ISSN 15451569. 
Offerdal K, Jebens N, Syvertsen T, Blaas H-GK, Johansen OJ \& Eik-Nes SH. Prenatal Ultrasound detection of facial clefts: a prospective study of 49314 deliveries in a non-selected population in Norway. Ultrasound in Obstetrics and Gynecology, Vol. 31, No. 6, (June 2008), pp. 639-646, ISSN 0960-7692

Demircioglu M, Kangesu L, Ismail A, Lake E, Hughes J, Wright S \& Sommerlad BC. Increasing accuracy of antenatal ultrasound diagnosis of cleft lip with or without cleft palate, in cases referred to the North Thames London Region. Ultrasound in Obstetrics and Gynecology, Vol. 31, No. 6, (June 2008), pp. 647-651, ISSN 0960-7692

Moore KL \& Persaud TVN (2003). The pharyngeal apparatus. In: The developing human: clinically oriented embryology. Moore KL \& Persaud TVN (Ed), pp. 201-240, Saunders, ISBN 0-7216-9412-8, Philadelphia, USA.

Pretorius D, House M, Nelson T \& Hollenbach, KA. Evaluation of normal and abnormal lips in fetuses: comparison between three- and two-dimensional sonography. American Journal of Roentgenology, Vol. 165, No. 5 (November 1995), pp. 165:1233, ISSN 16551233

Babcook CJ, McGahan JP, Chong BW, Nemzek WR, Salamat MS. Evaluation of fetal midface anatomy related to facial clefts: Use of US. Radiology, Vol. 201, No. 1 (Ocober 1996), pp. 113-118, ISSN 1527-1315

Filly RA \& Feldstein VA (2000). Ultrasound evaluation of normal fetal anatomy. In: Ultrasonography in Obstetrics and Gynecology, PW Callen (Ed.), 221-276, WB Saunders, ISBN 0-7216-8132-8, Philadelphia, USA.

UlmMR, Kratochwil A, Ulm B, Solar P, Aro G \& Bernaschek G. Three-dimensional ultrasound evaluation of fetal tooth germs. Ultrasound in Obstetrics and Gynecology, Vol. 12, No. 4, (October 1998), pp. 240-243, ISSN 0960-7692

Ulm MR, Kratochwil A, Ulm B, Lee A, Bettelheim D \& Bernaschek G. Three-dimensional ultrasonographic imaging of fetal tooth buds for characterization of facial clefts. Early fetal development, Vol. 55, No. 1 (May 1999), pp. 67-75, ISSN 0378-3782

Johnson DD, Pretorius DH, Budorick NE, Jones MC, Lou KV, James GM \& Nelson TR. Fetal lip and primary palate: three-dimensional versus two-dimensional US. Radiology, Vol. 217, No. 1 (October 2000), pp. 236-239, ISSN 1527-1315

Campbell $\mathrm{S}$ and Lees CC. The three-dimenisonal reverse face (3D RF) view for the diagnosis of cleft palate. Ultrasound in Obstetrics and Gynecology, Vol. 22, No. 6, (June 2003), pp. 552-554, ISSN 0960-7692

Campbell S, Lees C, Moscoso G and Hall P. Ultrasound antenatal diagnosis of cleft palate by a new technique: the 3D 'reverse face' view. Ultrasound in Obstetrics and Gynecology, Vol. 25, No. 1, (January 2005), pp. 12-18, ISSN 0960-7692

Pilu G \& Segata M. A novel technique for visualization of the normal and cleft fetal secondary palate: angled insonation and three-dimensional ultrasound. Ultrasound in Obstetrics and Gynecology, Vol. 29, No. 2, (February 2007), pp. 166-169, ISSN 09607692

Platt LD, DeVore GR \& Pretorius DH. Improving cleft palate/cleft lip antenatal diagnosis by 3-dimensional sonography. Journal of Ultrasound in Medicine, Vol.25, No. 11 (November 2006), pp.1423-1430, ISSN 1550-9613

Wong HS, Tait J \& Pringle KC. The fetal soft palate: not a nowhere land on 3D ultrasound. Ultrasound in Obstetrics and Gynecology, Vol. 30, No.4, (October 2007), pp. 484, ISSN 0960-7692 
Wong HS, Tait J \& Pringle KC. Viewing of the soft and hard palate on routine 3D ultrasound sweep of the fetal face - a feasibility study. Fetal Diagnosis and Therapy, Vol. 24, No.2, (August 2008); pp. 146-54., ISSN 1421-9964

Wong HS, Tait J \& Pringle KC. Examination of the secondary palate on stored 3D ultrasound volumes of the fetal face. Ultrasound in Obstetrics and Gynecology, Vol. 33, No. 4, (April 2009), pp. 407-11, ISSN 0960-7692

Wong HS, Tait J, Pringle KC. The use of oblique planes in assessing fetal cleft palate in stored 3D ultrasound volumes of fetal face. Ultrasound in Obstetrics and Gynecology, Vol. 36, Suppl. 1 (October 2010), pp. 249, ISSN 0960-7692 


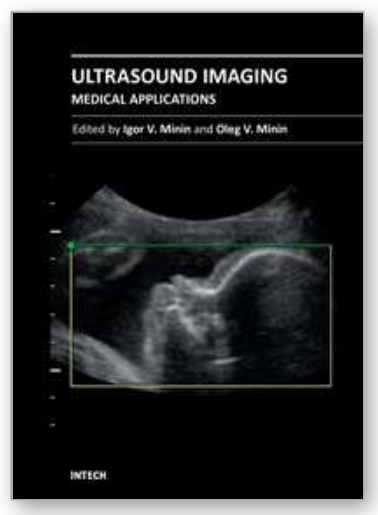

\author{
Ultrasound Imaging - Medical Applications \\ Edited by Prof. Oleg Minin
}

ISBN 978-953-307-279-1

Hard cover, 330 pages

Publisher InTech

Published online 23, August, 2011

Published in print edition August, 2011

This book provides an overview of ultrafast ultrasound imaging, 3D high-quality ultrasonic imaging, correction of phase aberrations in medical ultrasound images, etc. Several interesting medical and clinical applications areas are also discussed in the book, like the use of three dimensional ultrasound imaging in evaluation of Ashermanâ $€^{\mathrm{TM} S}$ syndrome, the role of 3D ultrasound in assessment of endometrial receptivity and follicular vascularity to predict the quality oocyte, ultrasound imaging in vascular diseases and the fetal palate, clinical application of ultrasound molecular imaging, Doppler abdominal ultrasound in small animals and so on.

\title{
How to reference
}

In order to correctly reference this scholarly work, feel free to copy and paste the following:

Hong Soo Wong and Kevin Craig Pringle (2011). Ultrasound Imaging of the Fetal Palate, Ultrasound Imaging Medical Applications, Prof. Oleg Minin (Ed.), ISBN: 978-953-307-279-1, InTech, Available from:

http://www.intechopen.com/books/ultrasound-imaging-medical-applications/ultrasound-imaging-of-the-fetalpalate

\section{INTECH}

open science | open minds

\section{InTech Europe}

University Campus STeP Ri

Slavka Krautzeka 83/A

51000 Rijeka, Croatia

Phone: +385 (51) 770447

Fax: +385 (51) 686166

www.intechopen.com

\section{InTech China}

Unit 405, Office Block, Hotel Equatorial Shanghai

No.65, Yan An Road (West), Shanghai, 200040, China

中国上海市延安西路65号上海国际贵都大饭店办公楼405单元

Phone: +86-21-62489820

Fax: +86-21-62489821 
(C) 2011 The Author(s). Licensee IntechOpen. This chapter is distributed under the terms of the Creative Commons Attribution-NonCommercialShareAlike-3.0 License, which permits use, distribution and reproduction for non-commercial purposes, provided the original is properly cited and derivative works building on this content are distributed under the same license. 